\title{
Distribution and abundance of Chubut Steamerducks: an endemic species to Central Patagonia, Argentina
}

\author{
MARÍA LAURA AGÜERO, PABLO GARCÍA BORBOROGLU and \\ DANIEL ESLER
}

\begin{abstract}
Summary
We documented the breeding distribution and estimated abundance of Chubut Steamerducks Tachyres leucocephalus, a flightless waterbird endemic to a relatively small section of coastline in Patagonia, Argentina. The distribution of Chubut Steamerducks is restricted to approximately $700 \mathrm{~km}$ of coast. We counted 1,703 adult steamerducks at a subset of shorelines within their range and estimated 1,841 adults after correcting for visibility for shore-based surveys. To estimate adult densities in unsurveyed areas, we used two different methods of extrapolation, resulting in estimates of 1,587 and 1,832 adults. Combined with numbers from surveyed shorelines, the total breeding population size is estimated to be between 3,428 and 3,673 adults. In addition, we counted 1,899 juvenile steamerducks, which occur in irregular aggregations. The Interjurisdictional Marine Park in San Jorge Gulf contains about $46 \%$ of the entire population, which may provide some protection from disturbance and habitat destruction. However, oil pollution, other anthropogenic activities, and invasive species still pose potential threats to the population.
\end{abstract}

\section{Resumen}

Hemos documentado el rango de distribución y estimado el tamaño poblacional del pato vapor cabeza blanca Tachyres leucocephalus, un ave acuática no voladora endémica de una estrecha sección costera de Patagonia, Argentina. La distribución del pato vapor cabeza blanca esta restringida a aproximadamente $700 \mathrm{~km}$ de costa. Hemos contado 1,703 individuos a lo largo de sectores costeros discretos dentro de su rango de distribución, y estimado un total de 1,841 adultos luego de aplicar los correspondientes factores de corrección. Para estimar la densidad de adultos en los sectores no relevados, hemos utilizado dos métodos diferentes de extrapolación, resultando en un número estimado de 1,587 y 1,832 adultos. De esta forma, al sumar individuos relevados y estimados, el tamaño poblacional oscilaría entre los 3,428 y 3,673 adultos reproductores. Asimismo, hemos contado un total de 1,899 juveniles de pato vapor cabeza blanca, los cuales ocurren en agregaciones regulares. El Parque Interjurisdiccional Marino Golfo San Jorge alberga alrededor del $46 \%$ de la población, lo cual podría representar una medida de protección frente a disturbios o destrucción del hábitat. Sin embargo, la contaminación por hidrocarburos y otras actividades de orígen antrópico junto con la introducción de especies, representan un potencial peligro para la población completa.

\section{Introduction}

Estimates of population size are a crucial tool for setting conservation priorities (Karanth and Nichols 1998, Kéry 2002, Thompson 2002). This information allows for the assessment of future changes in population size and hence evaluation of the impacts of habitat loss, pollution, or other 
threats (Buckland et al. 2008). In addition, numerical estimates as well as population trends and distribution are important criteria of the IUCN Red List classification scheme (IUCN 2001).

Steamerducks (genus Tachyeres) are large diving ducks limited in distribution to southern South America. Four species are currently recognised (Weller 1976, Humphrey and Thompson 1981), including three flightless species: Chubut Steamerduck Tachyres leucocephalus, Magellanic Steamerduck T. pteneres, and Falkland Steamerduck T. brachypterus, and one flying species: Flying Steamerduck T. patachonicus. Flying Steamerducks breed in both freshwater and marine habitats; the three flightless species are strictly marine throughout the annual cycle.

All species of Tachyeres are monogamous and form lasting, perhaps lifelong pair bonds (Humphrey and Livezey 1985). Males are extremely territorial and fight frequently (Livezey and Humphrey 1985). All members of the genus feed primarily on large molluscs and crustaceans obtained from the bottom by diving and shallow-water foraging, or found exposed during low tide (Murphy 1936, Weller 1972, Livezey 1989).

Chubut Steamerduck is endemic to the coast of central Patagonia, Argentina (Madge and Burn 1988). There is little information about the distribution or abundance of the species beyond speculative estimates. Numbers have been believed to be fewer than 10,000 individuals (Wetlands International 2002). However, Wetlands International (2002) also states that "the population may only number a few hundred (D. Scott pers. obs.)". This uncertainty regarding distribution and basic population size hinders adequate design and implementation of conservation and management actions. Chubut Steamerducks are highly territorial, particularly during the breeding season, which is thought to be an important defence of nest site, food, and broods (Vallentin 1924, Weller 1972, 1976). This territorial behaviour may lead to dispersion of nesting pairs and thus may limit local densities. Large flocks of non-breeding birds, primarily juveniles, are excluded from territories and occur in communal aggregations (Murphy 1936, Pettingill 1965, Weller 1972, 1976). We conducted the first surveys of the Chubut Steamerduck to (I) document the breeding range of the species, and (2) estimate abundance, which will allow determination of population trends in the future. These basic attributes constitute critical information for directing subsequent conservation for this poorly-known species.

\section{Methods}

\section{Study area and census techniques}

Our study area corresponded to Chubut Province, Patagonia, Argentina, whose coastline is $1,490 \mathrm{~km}$ in length. To determine the breeding distribution of Chubut Steamerducks and estimate their abundance, we surveyed $732 \mathrm{~km}$ of mainland (divided in segments along the whole Chubut coast) and $103 \mathrm{~km}$ of island coast (58 islands and islets; Figure 1 ). To accurately determine the breeding range, we surveyed coastal sectors located at both northern and southern extremes of the study area to confirm there were no breeding pairs. Surveys were conducted from 2006 to 2008 during September to December, which is the breeding season of Chubut Steamerducks. Although the Flying Steamerduck has been documented in coastal Chubut, we are confident that our observations reflect the abundance and distribution of the much more common Chubut Steamerducks. Flying Steamerduck has been described previously as occurring in our study area only as a non-breeding straggler during the breeding season, or during winter (Humphrey and Livezey 1982, Livezey and Humphrey 1992). Also Chubut Steamerduck is distinct from Flying Steamerduck in a number of characters. In general, the greater bulk, relatively shorter wings, and thicker bill of the Chubut Steamerduck can be distinguished at close range. The more slender neck and longer and more curved tail of Flying Steamerduck can be evident, particularly if the birds adopt the "alert" posture in which the back is arched and neck extended (Humphrey and Thompson 1981, Livezey and Humphrey 1992). When we found pairs and broods, we closely examined the plumage of ducklings and breeding females because these are absolutely diagnostic for identifying each species (Delacour 1975, Livezey and Humphrey 1992, Edelaar and García Borboroglu 2005). 


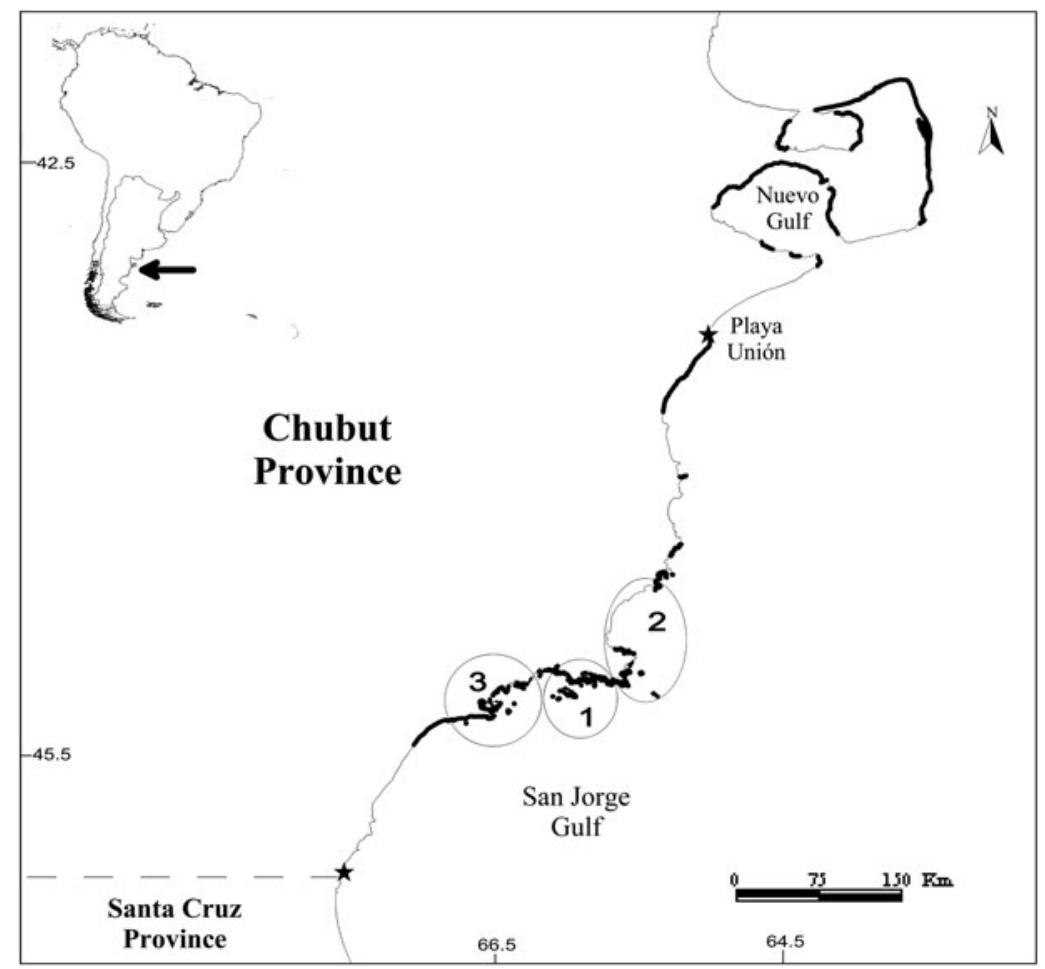

Figure 1. Surveyed coastal sectors are shown as thick lines and distribution range is limited by filled stars. Areas with higher concentrations of individuals: 1. Bahía Melo; 2. Bahía Camarones/ Cabo Dos Bahias, and 3. Bahía Bustamante/Caleta Malaspina.

Logistical constraints prevented us from surveying the entire coast. Inclusion or exclusion of survey segments was based on logistical considerations, not a priori expectations of the likelihood of finding steamerducks. Surveyed areas were broken into discrete survey segments according to accessibility (cities, towns, landowner permissions).

All surveyed shoreline segments, including island and mainland coasts, were searched using either boat or ground counts, depending on weather conditions and topography. For counts from a boat, we used an inflatable with an outboard motor travelling at a speed of 5-10 knots, between 10 and $15 \mathrm{~m}$ from the coast. Ground counts were conducted on foot. With both methods, we used $10 \mathrm{x} 40$ binoculars and counted any observed steamerducks. Chubut Steamerducks are closely associated with the shoreline, and we assume that we did not miss birds due to their distance from shore. We used GPS to measure the linear distances navigated and walked, both in island and mainland coast segments. The perimeters of the island were estimated using nautical charts (Servicio de Hidrografía Naval Argentina), published literature (García Borboroglu et al. 2002), and GIS. During surveys, steamerducks were identified based on plumage and bill characteristics as adult males and females, breeding pairs, or juveniles. Steamerducks appear to reach sexual maturity at 2-3 years of age (Weller 1972, Delacour 1975, Johnsgard 1978) and the fledging period is about 12 weeks (Weller 1972, Johnsgard 1978). Thus, we consider flocks of non-breeders and post-fledging individuals as juveniles. Previous observations in the last 20 years indicate that, during the breeding season, juvenile groups are consistently located in the same restricted sites (pers. obs.)

To quantify differences between surveys done by boat and from the ground, we used both methods to simultaneously count ducks along 23 coastal segments with varying lengths ( 0.44 and $4.72 \mathrm{~km}$ ) 
and compared results using the Wilcoxon paired-sample test. The analysis was done for the total number of ducks and for each cohort (adult males and females, breeding pairs, and juveniles). If there were significant differences between survey methods, we developed correction factors based on the ratio of the numbers from boat surveys (which were consistently higher) to the number of ducks from ground surveys. We assumed that boat surveys were as close to a complete census as possible.

\section{Abundance estimation}

To estimate numbers of steamerducks, we applied correction factors as appropriate based on cohort and survey type (see Results) to survey data, and calculated the number of ducks per kilometre of coast (density) for each surveyed segment. In addition, two different methods were used to extrapolate adult densities to unsurveyed segments within the distribution range of the species. In both, densities of surveyed coastal segments were calculated separately for island segments and mainland segments, and differences were tested using the Mann-Whitney U-test. If differences were statistically significant, island and mainland densities were used separately to extrapolate to the corresponding unsurveyed coastal segments.

Method \# 1. We calculated an average island density by dividing the total number of adults counted in each island segment by the total number of kilometres of those segments surveyed. Likewise, we used an average to determine mainland density by dividing the number of adults seen by the total number of coastal kilometres surveyed. We used those calculated densities to estimate adult densities and subsequently abundance on unsurveyed island and mainland segments.

Method \# 2. The unsurveyed islands were estimated using the average density from the four closest islands. The abundance of the mainland segments not counted was estimated using an average density calculated from the two adjacent mainland segments surveyed.

\section{Results}

\section{Census techniques}

Thirty-nine percent more adults (pairs, males and females combined) were counted from the boat than from land during simultaneous surveys $(z=-2.5, n=23, P<0.05$; Wilcoxon paired-sample test). By boat, we counted $26 \%$ more breeding pairs $(z=-2.13, n=23, P<0.05$; Wilcoxon paired-sample test) and $87 \%$ more males than when we counted from land $(z=-2.11, n=23$, $P<0.05$; Wilcoxon paired-sample test). Numbers of females counted from the boat and from land were similar $(z=-0.98, n=23, P>0.05$; Wilcoxon paired-sample test). We used a correction factor for the number of breeding pairs and males when counts were made on land. Numbers of juveniles were similar between boat and ground surveys $(z=-0.45, n=23, P>0.05$; Wilcoxon paired-sample test).

\section{Breeding distribution}

Chubut Steamerducks have been described previously as a locally common species from Península Valdés $\left(42^{\circ} \mathrm{Oo}\right.$ 'S $\left.65^{\circ} \mathrm{O}^{\prime} 31.11^{\prime \prime} \mathrm{W}\right)$ south through the Bahía Camarones to the northernmost regions of San Jorge Gulf $\left(45^{\circ} 14^{\prime} 49.66^{\prime \prime} \mathrm{S}, 66^{\circ}{ }_{4} 1^{\prime} 58.43^{\prime \prime} \mathrm{W}\right)$ along the marine coastlines of Chubut (Humphrey and Thompson 1981, Livezey and Humphrey 1992). However, in our survey, the northernmost and southernmost records of breeding Chubut Steamerducks corresponded to Playa Unión, Rawson $\left(43^{\circ} 20^{\prime} 38^{\prime \prime} \mathrm{S}, 65^{\circ} 3^{\prime} 19^{\prime \prime} \mathrm{W}\right)$ and near the Chubut-Santa Cruz Provincial border $\left(45^{\circ} 59^{\prime} 35^{\prime \prime} \mathrm{S}, 67^{\circ} 35^{\prime} 44^{\prime \prime} \mathrm{W}\right)$, respectively (Figure 1). Chubut Steamerduck has a restricted and non-uniform breeding distribution in Chubut Province. Steamerducks were more concentrated in the northern San Jorge Gulf sector, which contained about $46 \%$ of the adult Chubut Steamerduck population. 
The three areas with the highest concentrations of adult ducks were: Bahía Melo (26\% of the population, density 7 ducks $\mathrm{km}^{-1}$ ); Bahía Camarones/Cabo Dos Bahias ( $13 \%$ of the population, density 8.5 ducks $\mathrm{km}^{-1}$ ); and Bahía Bustamante/Caleta Malaspina ( $9 \%$ of the population, density 5.2 ducks $\mathrm{km}^{\mathrm{T}}$; Figure $\mathrm{I}$ ).

\section{Abundance estimation}

We directly observed 1,703 adult Steamerducks along $835 \mathrm{~km}$ of surveyed coastline. Applying the corresponding correction factor to segments surveyed from land only, we estimated a total number of adults for surveyed areas to be 1,841 adults. Average ( \pm SE) density of adults around islands $\left(14.6 \pm 2.3\right.$, range $=0.4-91.6$ ducks km${ }^{-1}$ ) was significantly higher than along the mainland coast $\left(4.1 \pm 1.0\right.$, range $=0.2-13.6$ ducks $\left.\mathrm{km}^{-1}\right)(U=164, P<0.05$, Mann-Whitney U-test $)$.

We estimated numbers in the unsurveyed area using the weighted average density of islands and mainland coast to be 1,832 adults (Method 1). Using Method 2, we estimated that numbers of adults on unsurveyed segments were 1,587 adults. Therefore, we estimated the total number of adults to be between 3,428 and 3,673 steamerducks.

On the surveys, we recorded 1,899 juveniles, occurring in flocks varying from three to 103 individuals. Juvenile groups were observed in the same sites during several years, some of them reported from at least 1992. We did not mark birds, so it is unknown whether these juvenile groups were necessarily composed of the same individuals across years. Because of their irregular, clumped distribution, we could not extrapolate numbers of juveniles to unsurveyed segments, so this number represents a minimum value.

\section{Discussion}

Chubut Steamerducks were not uniformly distributed and were concentrated in the northern San Jorge Gulf sector, with a total population likely to be around 3,500 adults and a minimum of approximately 2,000 juveniles.

Chubut Steamerduck densities were higher on islands than mainland shorelines. Steamerducks prefer to nest on islands and islets, mostly along shorelines within bays and inlets with shallow waters protected from waves and predominant winds, and high vegetation cover (Agüero et al. 2010); these characteristics are common features of the San Jorge Gulf, which may explain why Chubut Steamerducks are abundant in this area. Moreover, islands tend to be predator-free, allowing potential higher breeding success for flightless birds (Lack 1968). Several potential mainland mammalian predators have been recorded, which include the Hairy Armadillo Chaetophractus villosus, Argentine Grey Fox Pseudalopex griseus, Patagonian Ferret Galictis cuja, Geoffroy's Cat Felis geoffroyi, and Puma Puma concolor. Avian predators are prevalent in island localities. In our study area, two species of birds were observed to predate eggs of Chubut Steamerducks: Kelp Gulls Larus dominicanus and Crested Caracara Polyborus plancus (Agüero et al. 2010). Great Skuas Catharacta skua, Giant Petrels Macronectes giganteus and Kelp Gulls prey upon ducklings of Tachyeres spp. (Pettingill, 1965). Currently, $38 \%$ of the expanding Patagonian population of Kelp Gull $(43,875$ breeding pairs) breeds in the northern San Jorge Gulf sector, sympatrically with Chubut Steamerducks, on $72 \%$ of the islands (Lisnizer et al. 2011).

The recently designated Interjurisdictional Marine Park in San Jorge Gulf contains about $46 \%$ of the entire population of Chubut Steamerducks and may provide some protection from disturbance and habitat destruction within its jurisdiction. However, there are other potential threats to Chubut Steamerducks that marine park designation does not protect against. Specifically, oil exploration and extraction are taking place within $100 \mathrm{~km}$ of the heart of the population of Chubut Steamerducks. This is a major concern, since Argentina is rapidly developing oil resources on this part of the continental shelf. Moreover, the northward Falkland current would take any spill occuring in the development area directly towards Chubut 
Steamerduck breeding range. In the last 30 years, three major oil spills hit key coastline sectors where steamerducks bred (García Borboroglu et al. 2008), causing massive mortalities of steamerducks (D. Pautaso pers. comm.). No estimations of the number of affected birds were made and, because this study presents the first abundance estimation, there are no population trend data available for the species. The oil spills also harmed the intertidal feeding areas of steamerducks. Contaminants derived from oil are still found in the sediment and on rocky surfaces of both steamerduck breeding and foraging grounds (Gil et al. 1999, Commendatore et al. 2000). These events may undoubtedly have caused a dramatic reduction in the population size and in the quality of habitat, hindering the potential for recovery.

The risk of oil spill due to development or transport can be catastrophic to seabird populations (Bourne 1976, Holmes and Cronshaw 1977, Ohlendorf et al. 1978, Clark 1984). Direct lethal effects of oil contamination and indirect effects of oil spill on marine birds may include: (1) ingestion of, or exposure to, oil that negatively affects reproduction (McGill and Richmond 1979, Lewis and Malecki 1984, Trivelpiece et al. 1984); (2) ingestion of oil that leads to the development of pathological conditions in tissues and reduces overall physical condition (Fry and Lowenstine 1985); (3) loss of food due to prey mortality, and (4) clean-up operations associated with an oil spill (personnel and clean-up methods) that cause a significant disturbance to birds living in shoreline habitats (Maccarone and Bizorad 1994).

Another current threat is the presence of three introduced invasive species: the Green Crab Carcinus maenus, Asian Kelp Undaria pinnatifida, and the Acorn Barnacle Balanus glandula, all of which are causing dramatic changes to near-shore ecosystems (Casas et al. 2004, Hidalgo et al. 2005, Schwindt 2007) upon which steamerducks rely. The species is also exposed to several other potential anthropogenic threats, including macroalgae and guano harvesting (Piriz and Casas 1996, García Borboroglu and Yorio 2007). Egg-collecting has also been reported but appears to occur at very low intensity at a few sites (P. García Borboroglu unpubl. data). Other human activities that take place along the coast include tourism, recreation and nautical sports (Tagliorette and Losano 1996) and small-scale coastal fishing (Caille 1996).

The new marine park will attract many visitors, enhancing the development of tourist facilities. Therefore it is crucial to design and implement a management plan with a zoning scheme that would protect key breeding areas from harmful activities, such as the construction of piers and ports, the establishment of accomodation facilities, the development of acquaculture farms, the traffic of nautical vessels and terrestrial transport such as ATVs or $4 \mathrm{x} 4$ vehicles, and permits to camp, fish or hunt. In addition, the authorities should prepare an effective oil spill contingency plan. Finally, it is imperative to avoid the extraction of adults or eggs from the wild population. Future research should focus on a comprehensive monitoring of the population and on conducting demographic and genetic studies to be able to develop population viability analyses.

Chubut Steamerducks are flightless and have a low number of mature individuals restricted in their distribution and occurring close to the coast. In addition, because they require specific habitat features for breeding and foraging (Gatto et al. 2008, Agüero et al. 2010) they are particularly vulnerable to a wide array of threats. In conclusion, our study, in combination with the current and increased threats mentioned, indicates that the Chubut Steamerduck is of significant conservation concern and suggests that its IUCN listing should be upgraded and listed at least as 'Vulnerable'.

\section{Acknowledgements}

Research was funded by grants from OAK Foundation Grant in Marine Conservation - Duke University Marine Lab, Rufford Small Grants Foundation, Wildlife Conservation Society, Chubut Province Government, and Neotropical Bird Club. We thank Centro Nacional Patagónico (CONICET) for institutional support and Soriano S.A., Dirección de Fauna y Flora Silvestre, Secretaría de Turismo de la Provincia del Chubut, Laura Reyes, Luciana Musmeci, and Feliciano Abril and his family for logistical support. Dee Boersma, Pablo Yorio and Laura Reyes provided helpful comments on the manuscript. PGB thanks Luc Hoffmann for continuous support for his work. We thank José 
Saravia for statistical support. We are grateful to Darío Villarreal, Nestor Ortiz, Ricardo Vera, Fabián Quiroga, Mauricio Agüero, Nora Lisnizer, Alejandro Gatto, Agustina Gomez Laich, Alejandro Fernández Ajó, Marisol Píngaro, Vanina Roggio, Marlene Dherete, Laura López, María Mendez, Pablo Galesi, Jorge Owen, Hector Hernández, Jorge and Silvia Kriegel, for field assistance.

\section{References}

Agüero, M. L., García Borboroglu, P. and Esler, D. (2010) Nesting habitat of Chubut Steamerducks in Patagonia, Argentina. Emu 110: 302-306.

Bourne, W. R. P. (1976) Seabirds and pollution. Pp. 403-502 in R. I. Johnston, ed. Marine pollution. London, UK: Academic Press.

Buckland, S. T., Marsden, S. J. and Green, R. E. (2008) Estimating bird abundance: making methods work. Bird Conserv. Int. 18: 91108.

Caille, G. (1996) La pesca artesanal en las costas de Patagonia: una visión global. Pp. 1-14 in Plan de manejo Integrado de la zona costera Patagónica. Puerto Madryn, Argentina: Fundación Patagonia Natural. (Technical Report 7).

Casas, G., Scrosati, R. and Piriz, M. L. (2004) The invasive kelp Undaria pinnatifida (Phaeophyceae, Laminariales) reduces native seaweed diversity in Nuevo Gulf (Patagonia, Argentina). Biol. Invasions 6: 411-416.

Clark, R. B. (1984) Impact of oil pollution on sea- birds. Environ. Pollution 33:1-22.

Commendatore, M. G., Esteves, J. L. and Colombo, J. C. (2000) Hydrocarbons in coastal sediments of Patagonia, Argentina: levels and probable source. Mar. Pollution Bull. 40: 989-998.

Delacour, J. (1975) The waterfowl of the world. New York, USA: Arco Publishing Company, Inc.

Edelaar, P. and García Borboroglu, P. (2005) Identification of steamerducks Tachyeres spp.: unknowns, controversies, misunderstandings and possibilities. IX Reunión Argentina de Ornitología. Ciudad Autónoma de Buenos Aires, Argentina: Museo Argentino de Ciencias Naturales Bernardino Rivadavia.

Fry, D. M. and Lowestine, L. J. (1985) Pathology of common murres and Cassin's auklets exposed to oil. Arch. Environ. Contamination and Toxicol. 14: 725-737.
García Borboroglu, P. and Yorio, P. (2007) Breeding habitat requirements and selection by the threatened Olrog's gull Larus atlanticus. Auk 124: 1201-1212.

García Borboroglu, P., Yorio, P., Boersma, P. D., Del Valle, H. and Bertellotti, M. (2002) Habitat use and breeding distribution of Magellanicus Penguins in northern San Jorge Gulf, Patagonia, Argentina. Auk 119: 233-239.

García Borboroglu, P., Boersma, P. D., Reyes, L. M. and Skewgar, E. (2008) Petroleum pollution and penguins: Marine conservation tools to reduce the problem. Pp. 339356 in T. N. Hofer, ed. Marine pollution: New research. Hauppauge, NY: Nova Science Publishers.

Gatto, A., Quintana, F. and Yorio, P. (2008) Feeding behavior and habitat use in a waterbird asssemblage at a marine wetland in Coastal Patagonia, Argentina. Waterbird 31: 463-471.

Gil, M. N., Harvey, M. and Esteves, J. L. (1999) Heavy metals in intertidal sediments from Patagonian coast, Argentina. Bull. Environ. Contamination Toxicol. 63: 52-58.

Hidalgo, F., Barón, P. J. and Orensanz, J. M. (2005) A prediction come true: the green crab invades the Patagonian coast. Biol. Invasions 7: 547-552.

Holmes, W. N. and Cronshaw, J. (1977) Biological effects of petroleum on marine birds. Pp. $359-398$ in D. C. Malins, ed. Effects of petroleum on arctic and subarctic marine environments and organisms. New York, USA:. Academic Press.

Humphrey, P. S. and Livezey, B. C. (1982) Molts and plumage of Flying Steamerducks (Tachyeres patachonicus). Occas. $\mathrm{Pa}$ per Mus. Nat. Hist. Kansas 103: 1-30.

Humphrey, P. S. and Livezey, B. C. (1985) Nest, eggs, and downy young of the Whiteheaded Flightless Steamer-duck. Ornithol. Monogr. 36: 944-953. 
Humphrey, P. S. and Thompson, M. C. (1981) A new species of steamer-duck (Tachyeres) from Argentina. Occas. Paper Mus. Nat. Hist. Kansas 95: 1-12.

IUCN (2001) IUCN Red List categories and criteria: Version 3.1. Gland, Switzerland and Cambridge, UK: IUCN Species Survival Commission.

Johnsgard, P. A. (1978) Ducks, geese, and swans of the world. Lincoln, Nebraska: University of Nebraska.

Karanth, K. U. and Nichols, J. D. (1998) Estimation of tiger densities in India using photographic captures and recaptures. Ecology 79: 2852-2862.

Kéry, M. (2002) Inferring the absence of a species - a case study of snakes. J. Wildl. Manage. 66: 330-338.

Lack, D. (1968) Ecological adaptations for breeding in birds. London, UK:.Metheun.

Lewis, S. J. and Malecki, R. A. (1984) Effects of egg oiling on larid productivity and population dynamics. Auk 101: 584-592.

Lisnizer, N., García Borboroglu, P. and Yorio, P. (2011) Spatial and temporal variations in Kelp Gull population trends in northern Patagonia, Argentina. Emu. In press.

Livezey, B. C. (1989) Feeding morphology, foraging behavior, and foods of steamerducks (Anatidae: Tachyeres). Occas. Paper Mus. Nat. Hist. Kansas 126: 1-41.

Livezey, B. C. and Humphrey, P. S. (1985) Territoriality and interspecific aggression in steamer-ducks. The Condor 87: 154-157.

Livezey, B. C. and Humphrey, P. S. (1992) Taxonomy and identification of steamerducks (Anatidae: Tachyeres). Lawrence, Kansas: Museum of Natural History, University of Kansas.

Maccarone, A. D. and Bizorad, J. N. (1994) Gull and waterfowl populations in the Arthur Kill. Pp. 201-214 in J. Burger, ed. Before and after an oil spill: the Arthur Kill. New Brunswick, NJ: Rutgers University Press.

Madge, S. and Burn, H. (1988) Wildfowl: an identification guide to the ducks, geese and swans of the world. Boston and New York: Houghton Mifflin Company.

McGill, P. A. and Richmond, M. E. (1979) Hatching success of great black-backed gull eggs treated with oil. Bird-Banding 50: 108-113.

Murphy, R. C. (1936) Oceanic birds of South America. New York, USA:.American Museum of Natural History.

Ohlendorf, H. M., Risebrough, R. W. and Vermeer, K. (1978) Exposure of marine birds to environmental pollutants. Washington, USA: U.S. Fish Wildlife Service. (Wildlife Research Report 9).

Pettingill, O. S. Jr. (1965) Kelp Geese and Flightless Steamer Ducks in the Falkland Island. Living Bird 4: 65-78.

Piriz, M. L. and Casas, G. (1996) Macroalgas de interés comercial en las costas del sur de Chubut y norte de Santa Cruz. Pp. 1-36 in Plan de manejo integrado de la zona costera Patagónica. Puerto Madryn, Argentina: Fundación Patagonia Natural. (Technical Report 26).

Schwindt, E. (2007) The invasion of the acorn barnacle Balanus glandula in the south-western Atlantic 40 years later. J. Mar. Biol. Assoc. United Kingdom 87: 1219-1225.

Tagliorette, A. and Losano, P. (1996) Demanda turística en áreas costeras protegidas de la Patagonia. Pp. 1-3o in Plan de manejo integrado de la zona costera $\mathrm{Pa}$ tagónica. Puerto Madryn, Argentina: Fundación Patagonia Natural. (Technical Report 25).

Thompson, W. L. (2002) Towards reliable bird surveys: accounting for individuals present but not detected. Auk 119: 1825.

Trivelpiece, W. Z., Butler, R. G., Miller, D. S. and Peakall, D. B. (1984) Reduced survival of chicks of oil-dosed adult Leach's stormpetrels. Condor 86: 81-82.

Vallentin, R. (1924) Zoology. Pp. 285-335 in V. F. Boyson The Falkland Islands. Oxford, UK: Clarendon Press.

Weller, M. W. (1972) Ecological studies of Falkland Islands' waterfowl. Wildfowl 23: 25-44.

Weller, M. W. (1976) Ecology and behaviour of steamer ducks. Wildfowl 27: 45-53.

Wetlands International (2002) Waterbird population estimates - Third edition. Wageningen, The Netherlands: Wetlands International. 
MARÍA LAURA AGÜERO*

Centro Nacional Patagónico (CONICET), Boulevard Brown 2915, U9120ACF, Puerto Madryn, Chubut, Argentina.

\section{PABLO GARCÍA BORBOROGLU}

Centro Nacional Patagónico (CONICET), Boulevard Brown 2915, U9120ACF, Puerto Madryn, Chubut, Argentina.

University of Washington, Department of Biology, Box 351800, Seattle, WA 98195-1800, USA.

\section{DANIEL ESLER}

Centre for Wildlife Ecology, Simon Fraser University, 5421 Robertson Road, Delta, BC V4K3 $\mathrm{N}_{2}$. Canada.

${ }^{*}$ Author for correspondence; e-mail: laguero@cenpat.edu.ar

Received 28 October 2010; revision accepted 14 May 2011;

Published online 7 September 2011 